\title{
Preparing for consultancy
}

\author{
Michael Philpot
}

The article by Drs Loane and Barker in this issue is one of a number of 'consumer' surveys published in the Psychiatric Bulletin over recent years. The consumers in this case are, of course, newly appointed consultants in old age psychiatry asked to recall the usefulness of their training as senior registrars in the light of their present responsibilities. Fortunately most seemed satisfied with what training they had recetved, particularly in clinical matters, although training in management was found wanting. With regard to the latter, some aspects of the modern National Health Service (NHS) militate against creating successful experiences for the higher trainee. Shadowing of managers can be very beneficial if the managers can be persuaded to make the commitment. But even then it may only enable the trainees to observe the 'soft' end of management as much of the real decision-making is made in closed groups, and other important activities are also confidential.

The report identifies a number of interesting issues, not the least of which is a list of the training experiences thought most relevant to successful consultantship. Professor Copeland (1992) has written that "higher training is essential in order to ensure a basic level of skills which all trainees will attain and thus avoid the considerable variations in competence which used to occur" (my italics). There is no clear definition of what constitutes a basic level but Copeland goes on to list a number of entirely worthy principles which should govern higher training in general. The first of these, and probably the most important, is that the trainee should have a competent teacher. There is precious little indication of what that might mean in objectlve terms, although surveys like the present one help to identify what might form the content of teaching and supervision.

But is it reasonable for higher trainees to expect to be 'prepared for consultancy' in the way that is implied by Loane and Barker? Is an individual's sense of unpreparedness a valid indicator of defective or deficient training? Or have prospective consultants been so sensitised by the requirements of various organisations that they have unrealistic expectations of training?
A cynic might argue that one can only learn how to be a consultant 'on the job'. The survey partially confirms this view. It appears that working as a surrogate consultant is the most useful type of experience: for example, having sole responsibility for a part of the catchment area, sitting in on management meetings and appointments boards, and working in general practice surgeries or residential homes. The same cynic might argue that the goals of training have been taken to extremes in old age psychiatry where it has sometimes seemed that new consultants should be prepared to set up entire services single-handedly from scratch. This may have been the case in the early days of the speciality but does not necessarily match with the current structure of the NHS.

A previous survey of old age psychiatry senior registrars (Beats et al, 1992) concluded that many senior registrars felt under pressure to take up posts before full training (although what 'full training might have been was not made clear). Some years ago it was fashionable to attempt to become a consultant as soon as possible. It appears to me that the present day requirements have dampened this ambition. Why become a hard-pressed psychogeriatrician working up to 15 hours a day (Benbow \& Jolley. 1993) when one can spend at least three years being supernumerary with one day off a week (Copeland, 1992)? In any case, is there anywhere decent left to work as a consultant? Many of the unfilled consultant old age psychiatry posts (now in excess of 60 in England and Wales alone) are unattractive, with large catchment area populations, poor resources and a lack of opportunities for the academically minded, so that desperate employers have taken to offering inflated salaries and other benefits as incentives.

The next survey might be aimed at determining what it is that makes working as a newly appointed consultant bearable, apart from contact with patients that is. In my case it was working with a strong team of people who could be trusted, consultant colleagues who provided real support and enabled one to actually take research time, and not having to travel to work on Network South-East. 


\section{References}

BEATS, B., BAGLEY, G., BANKS, V., et al (1992) Higher training in old age psychlatry: a survey of senior registrars experiences. Psychiatric Bullettr, 16, 622-624.

BENBOw, S. \& JoLEY, D. (1993) All work? A day in the life of geriatric psychlatrists. International Joumal of Gerlatric Psychlatry. 8, 1019-1022.
COPELAND, J. (1992) Higher training: what is it trying to achieve and what is its rationale? Psychiatric Bullettr. 16. 391-395.

Michael Philpot, Consultant in Old Age Psychiatry, Maudsley Hospital, Denmark Hill, London SE5 8AZ

\title{
Newly appointed consultants in old age psychiatry and the adequacy of higher training
}

\author{
Ruth Loane and Andrew Barker
}

\begin{abstract}
This paper reports on a survoy of nowty appolnted consultionts in old age poychiatry. The questionnaire aiked for opinions on the adequacy of higher froining in a number of areas such as clinical, manogement, teaching, supervition and resecorch. In addition vbows were sought on particulaty valuctible experiences in preparation for consullancy. The results show that overell cliniced fraining wos judged to be good, while troining in some non-clinical crecs, eapectally manogement, wos found to be inauilicient. The importance of manogement training ts emphastsed and some valuable troining experiences are highilighted.
\end{abstract}

It is essential for old age psychiatry services to have consultants who have been adequately prepared for the role which includes organisation of the service, clinical practice, education and research (Arie \& Jolley, 1982). Some newhy appointed consultants have expressed the view that areas of their work were insufficiently covered during their higher training. In order to investigate this further the Senior Registrar Group of the Section of Old Age Psychiatry carried out a survey of newly appointed consultants in old age psychiatry to assess adequacy of training in a number of areas.

\section{The study}

In 1994, 43 newiy appointed (within the previous five years) consultants were identified through the Section of Old Age Psychiatry and a questionnaire was sent to each of them. The questionnaire covered length of higher training. clinical, management, research and teaching experience and additional areas, such as supervision and recruitment. Further comments and suggestions were encouraged, for example on ways in which higher training might be improved, or particularly valuable training experiences.

\section{Findings}

Thirty-five (81\%) completed questionnaires were recetved from consultants who had experience of 15 training schemes from a wide geographical area. The average length of training was three and a half years and four respondents had completed part-time higher training.

\section{Clinical experience}

Table 1 shows the various areas of clinical experience that respondents had been exposed to during higher training and how good this experience was in preparing them for consultancy. Overall, clinical experience was felt to be satisfactory. Particularly valuable experience included a three-month locum, responsibility for a geographical area with minimal supervision, experience of working with geriatricians, liaison clinic in general practice surgery, and liaison with nursing/residential homes. 